\title{
Tolerance of Anadenanthera peregrina to Eucalyptus camaldulensis and Eucalyptus grandis Essential Oil as Condition for Mixed Plantation
}

\author{
Neimar de Freitas Duarte ${ }^{1 *}$, Decio Karam ${ }^{2}$, Elizabeth Uber Bucek ${ }^{3}$ and Maria Rita Scotti \\ Muzzi $^{4}$ \\ ${ }^{1}$ Instituto Federal de Minas Gerais; Av.Prof. Mario Werneck, 2590; 305751-180; Belo Horizonte - MG - Brasil. \\ ${ }^{2}$ Embrapa Milho e Sorgo; Rod MG $424 \mathrm{Km}$, 65; Sete Lagoas - MG - Brasil. ${ }^{3}$ Universidade de Uberaba; Av. Nenê \\ Sabino, 1801; Uberaba - MG - Brasil. ${ }^{4}$ Departamento de Botânica; Instituto de Ciências Biológicas; Universidade \\ Federal de Minas Gerais; Av. Antônio Carlos, 6627; Belo Horizonte - MG - Brasil
}

\begin{abstract}
With the purpose of selecting the species of woody Caatinga for mixed plantations with Eucalyptus spp., the allelophatic effects of E. camaldulensis and E. grandis essential oil were studied on the growth activities of Anadenanthera peregrina. The plants were closed in glass chambers in the presence of volatile oil of E. camaldulensis or $\mathrm{E}$. grandis at the concentration of $13 \mathrm{nl.cm}$. The number of leaves, height and diameter at soil lever were compared before, immediately after and after 30 days. Chlorophyll a and b, carotenoids and dry mass were evaluated after the treatment application. There was no inhibitory effect of $\mathrm{E}$. camaldulensis and $\mathrm{E}$. grandis oils on A. peregrina. E. camaldulensis, which was more adapted to semi-arid conditions, was planted in mixture stands with two native legume species, inoculated with Rhizobium and arbuscular mycorrhizal fungi. E. camaldulensis did not inhibit native species growth after two years of cultivation.
\end{abstract}

Key words: Allelophatic, Caatinga; angico

\section{INTRODUCTION}

The negative direct or indirect plant effects over the biotic environment such as other plants or soil microorganisms are known as allelopathy. Plants release secondary metabolites into the environment, air, water and soil, through volatilization and root exudates (Deuber 1992). The Eucalyptus and Corymbia species, considered as notorious allelophatic tree although most often study plants, are commonly used in afforestation models over the world, due to their fast growth, good adaptation to different soil and climatic conditions and high timber value. Several studies have revealed that some Eucalyptus and Corymbia species may exert allelophatic effect by soluble metabolites lixiviation (May and Ash 1990; Kohli 1990) or by volatiles terpenoid compounds (Kohli and Singh 1991). The soluble fraction is transported by percolation and is absorbed by others plants, which can be used by the microorganisms or adsorbed by the clays, participating in soil cation exchange capacity (CEC). The effects exerted by the allelophatic terpenoid volatile compounds that are found in the environment in the form of vapor (Muller et al.1964) depend on the partial pressure of terpenoids in the air (Singh et al. 1993). The

*Author for correspondence: neimar@ifmg.edu.br 
bactericide effect exhaled by the leaves of Eucalyptus globulus (volatile fraction) has been reported for the medical purposes which allows the characterization for the purpose as stated in the medical world pharmacopedy.

It is also known that Eucalyptus spp. produces inhibitory substances for the soil bacterial growth (Della-Bruna et al. 1989; Moura et al. 1996), but, on the contrary, fungi population can be favoured (Della-Bruna et al 1989; Moura et al 1996).

Monocultures of some Eucalyptus species, over 40 years can retard the succession causing understory suppression (Del Moral et al. 1978; Bhaskar and Dasappa 1986; Singh et al. 1993). Eucalyptus can decrease the diversity in understory vegetation and borders of plantation in comparison to adjacent preserved areas (Suresh and Rai 1987; Kohli et al. 1992). Kohli et al. (1998) reported that E. globulus and $C$. citriodora oil inhibit the growth of the weed Parthenicum hysterophorus, through the inhibition of germination and cellular respiration, reduction of chlorophyll content and increment increase of water loss, leading to complete plant wilt after 15 days of oil exposition.

In Brazil, one of the most important programs of irrigation is on the São Francisco river. Known as Jaíba Project, it was established to increase the agricultural production and economic and social growth of the region. The Jaíba reserve is one of the largest protected areas of woody Caatinga and its natural vegetation is classified as "Dry Deciduous Forest" (Rizzini 1979), which has been subject to the destructive effects of deforestation and fire. Such environmental impact may result not only in the destruction of the biodiversity (flora and fauna), the chemical, physical and biological loss of soils, but also a perilously rapid loss of the wood stocks favoured by wood extraction, creating an impact on the local populations. It is important to consider that the affected populations are characterized by a high vulnerability, since they are among the poorest in the region. The demand for the wood by the farmers has become a continuous threat to the preserved area, revealing a need for a project of wood and energy provision for the local populations. Mixed-species plantations represent an alternative for revegetation with fast growing native species. Similar works in other regions such as Hawaii (De-Bell et al. 1985), Asia (Khanna 1997), Australia (May and Attiwill 2003), and Brazil (Gonçalves 2000) showed the advantages of legume use for increasing the plant growth and improving the soil fertility. For example, in a Eucalyptus plantation in Brazil showed the benefits of inoculated leguminous species for the reforestation of a riparian forest (Marques et al. 2001).

Anadenanthera peregrina ("angico-vermelho") is representative of Brazil's Caatinga biome and is a semideciduous plant, attaining up to $30 \mathrm{~m}$ height and $90 \mathrm{~cm}$ of diameter at breast height (DBH). In "Cerrado" and "Caatinga" biomes, this species is shorter (3 a 15 m) (Carvalho 1994). A. peregrina (angico) plants has been reported for the reforestation of degraded areas and for mixed plantings, mainly due to their fast initial development (Lorenzi 1992).

The aim of this work wasto examine the tolerance of A. peregrina to Eucalyptus essential oil and to test this effect under the field conditions. The plant growth under the mixed and pure stands was compared.

\section{MATERIALS AND METHODS}

\section{Effect of E. camaldulensis and E. grandis essencial oils}

The samples of adult leaves that had just fallen from 10 randomly selected trees of each species from E. camaldulensis and E. grandis were collected and sealed in plastic bags and stored at $4^{\circ} \mathrm{C}$ until processed (within two weeks). About 1.0 $\mathrm{Kg}$ of leaves was taken for essential oil extraction, obtained by steam-distilled according to Brazilian Pharmacopoeia $4^{\mathrm{a}}$ ed. The gravimetric method (Brazilian Pharmacopoeia $4^{\mathrm{a}}$ ed.) was used to determine the water content and volatile compounds in the leaves samples after drying at $100^{\circ} \mathrm{C} \pm 5^{\circ} \mathrm{C}$ to constant weight.

The seeds of Anadenanthera peregrina (L.) Spegazzini were collected in the Legal Reserve of Jaíba-Minas Gerais. After physical scarification and water immersion for $24 \mathrm{~h}$, the seeds were germinated in a humid chamber at $29^{\circ} \mathrm{C}$. Seedlings about $10 \mathrm{~cm}$ high were transplanted into plastic pots of $200 \mathrm{~g}$, filled with soil collected from the Jaíba Project. The fertilizers used inlcuded $32 \mathrm{~g}$ of $\mathrm{N}, 40 \mathrm{~g}$ of $\mathrm{P}_{2} \mathrm{O}_{5}$, and $16 \mathrm{~g}$ of $\mathrm{K}_{2} \mathrm{O}$ per $\mathrm{m}^{3} /$ subsoil. Six-week-old plants of angico placed in the chambers $\left(7500 \mathrm{~cm}^{3}\right)$ were fumigated with $13.0 \mathrm{nl}$ $\mathrm{cm}^{-3}$ of E. camaldulensis and E. grandis oil vapours, separately. The chambers of each native species were fumigated with the oil of $E$. camaldulensis and E. grandis, respectively as 


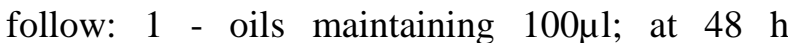
intervals the old vapours in the chambers were replaced by fresh ones. 2 - A chamber without oil vapours served as control. 3 - Plants which were maintained outside the chamber were considered as a check. Six replicates were made for each treatment/species using a randomized design. Before oil exposure and 5 and 35 days after the treatment, the number of leaves and height and diameter of each shoot were determined. After 35 days of exposure, the fresh and dry biomasses were determined. The A. peregrina blades leaves were divided into "leaflets" (pinnately), presenting also the rachis divided into many petioles and petiolules and because of this, it was difficult to measure the chlorophyll fluorescence in photosynthesis analyser. Alternatively, the plants of A. peregrina had the chlorophyll a, b and carotenoids content estimated according to Linchenthaler and Wellburn (1983), while the calculations were done as suggested by Daizy and Kohli (1991).

\section{Effect of mixed plantation on $A$. peregrina growth}

The experimental site $(1.5 \mathrm{ha} / \mathrm{site})$ was cleared of Carrasco (Araujo 1998) plants and cultivated as follows: E. camaldulensis intercropped with the native species A. peregrina and Myracrodruon urundeuva. The experimental design randomized block with nine treatments and three replicates blocks was followed using a density $3 \times 2 \mathrm{~m}$ in areas of Jaíba Project, which had lost original vegetation. Excluding the buffer trees, there were 40 plants per plot at the monoculture (plot size was $18 \times 20 \mathrm{~m}$ ), and in the mixed-species plots 60 trees occupied $540 \mathrm{~m}^{2}$. These nine treatments were irrigated for about 10 months.

The plots were cultivated as follows: a single plantation of A. peregrina; a single plantation of $A$. peregrina inoculated with Rhizobia and spores of arbuscular mycorrhizal fungi (AMF), a single plantation of E. camaldulensis, a single plantation of $E$. camaldulensis + AMF, a single plantation of M. urundeuva, a mixed plantation of A. peregrina + E. camaldulensis + M. urundeuva, a mixed plantation of A. peregrina (Rhizobia $+\mathrm{AMF})+E$. camaldulensis $+M$. urundeuva, a mixed plantation of A. peregrina $+E$. camaldulensis $(\mathrm{AMF})+M$. urundeuva, a mixed plantation of A. peregrina
$($ Rhizobia $+\mathrm{AMF})+$ E. camaldulensis $(\mathrm{AMF})+$ M. urundeuva.

\section{Inoculants}

The slow growing rhizobia strain BHICB-A10 was previously isolated from the nodules of $A$. peregrina at the Jaíba Project forest reserve, and screened for their effectiveness, under greenhouse and nursery conditions. The bacterial inocula were provided at $1.0 \mathrm{ml}$ per pot $\left(10^{7} \mathrm{cfu} / \mathrm{ml}\right)$, according to Somasegaran and Hoben (1985). Mycorrhizal fungi used were Gigaspora margarita, Scutelospora heterogama and Glomus etunicatum from UFMG laboratory collection. Endomycorrhizal inoculation was accomplished by placing $1.0 \mathrm{ml}$ of suspension composed by 50 spores per species and 150 spores $/ \mathrm{ml}$ in total of three species (G. margarita, S. heterogama and $G$. etunicatum) into each pot.

\section{Sampling and analyses}

Growth parameters, including the diameter at 30 $\mathrm{cm}$ above the ground and the height of all the plants, were recorded after $0.5,10,15$ and 20 months of the growth. The data were statistically analyzed by ANOVA and the means were compared by the Tukey's. The means were compared for the growth in the field only at 20 months.

\section{RESULTS AND DISCUSSION}

Evaluation of $E$. camaldulensis and $E$. grandis oils effect on $A$. peregrina plants in the laboratory

The results showed that leaves production, height growth (Fig. $1 \mathrm{~A}, \mathrm{~B}$ and C, D.), and fresh and dry biomass production of $A$. peregrina plants (Fig. 2 A, B and C, D) were not affected by the essential oils of E. camaldulensis and E. grandis after 35 days of exposure. The effect on the number of leaves and biomass production was influenced by the incubation procedure, especially in shoot parts. The chlorophyll $a, b$ and carotenoids analysis (Fig. $3 \mathrm{~A}$ and $\mathrm{B}$ ) showed that A. peregrina plants were not susceptible to the inhibitory effect of essential oils of E. camaldulensis and E. grandis. A. peregrina plants showed high tolerance to the inhibitory effects of both E. camaldulensis and E. grandis at $13 \mathrm{nl} . \mathrm{cm}^{-3}$. 
A

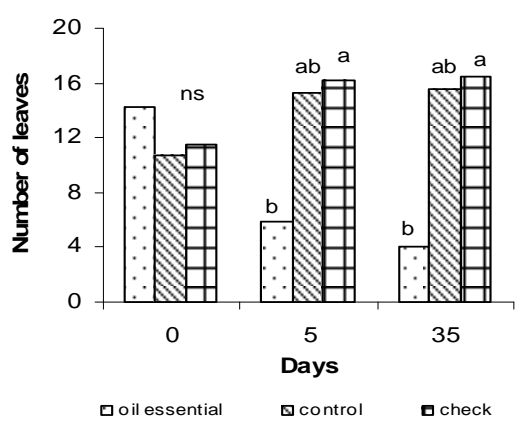

$\mathrm{C}$

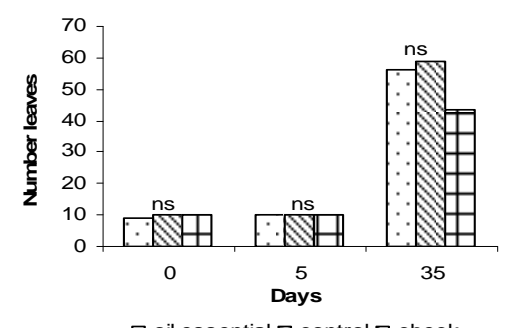

B

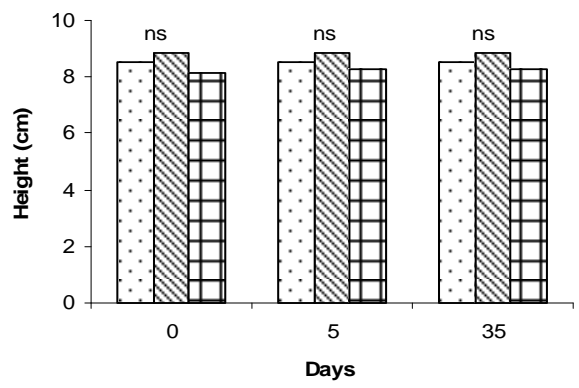

$\mathrm{D}$

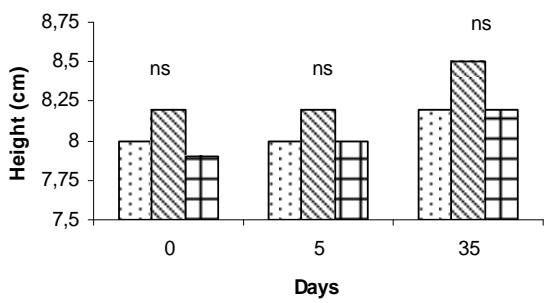

Figure 1 - E. camaldulensis oil effect in A. pegrina leaves number before and after 5 and 35 days of oil exposition (A), and plant height (cm) before and after 5 and 35 days of oil exposition (B). E. grandis oil effect in A. pegrina leaves number before and after 35 days of oil exposition (C), and plant height $(\mathrm{cm})$ before and after 5 and 35 days of oil exposition (D). Control= plants incubated without oil; oil= plants incubated with oil, and check = plants not incubated).

Means with different letters are significantly different as determined by Tuckey multiplerange test at the $5 \%$ confidence level $(\mathrm{P} \leq 0.05)$. Not significantly different.

A

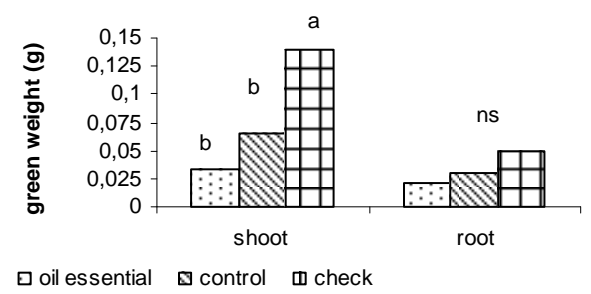

$\mathrm{C}$

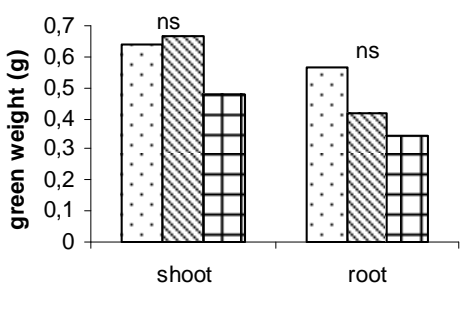

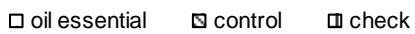

B

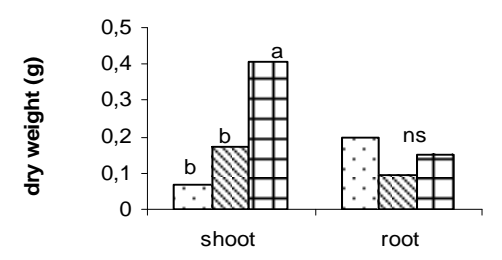

$\mathrm{D}$

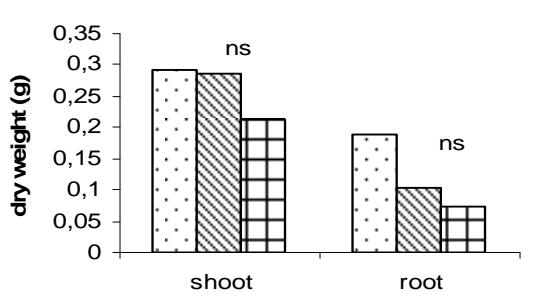

Figure 2 - E. camaldulensis oil effect in Anadenanthera pegrina green (A) and dry matter mass (B) production 5 and 30 days after the exposition. Eucalyptus grandis oil effect in Anadenanthera pegrina green (C) and dry matter mass (D) production 30 days after the exposition. (Control= plants incubated without oil; oil= plants incubated with oil, and check $=$ plants not incubated).

Means with different letters are significantly different as determined by Tuckey multiplerange test at the $5 \%$ confidence level $(\mathrm{P} \leq 0.05)$. NS: Not significantly different. 
A

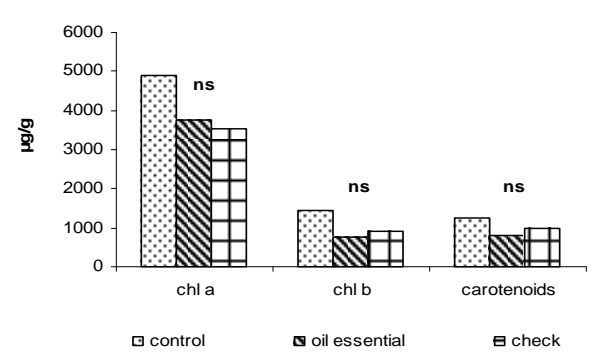

B

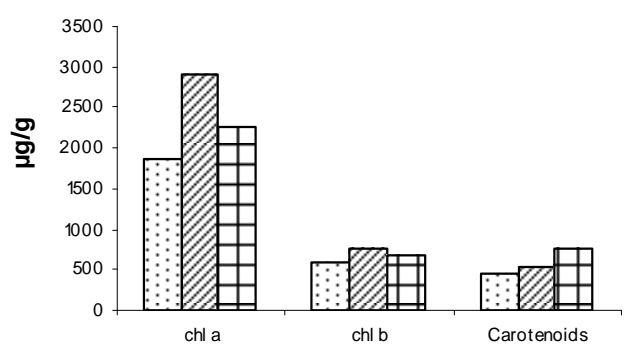

ns

Figure 3 - E. camaldulensis oil effect in chlorophyll a, b e carotenoids level in A. peregrina leaves (A) after 30 days of exposition. E. grandis oil effect in chlorophyll a, b and carotenoids level in A. peregrina leaves (B) after 30 days of exposition. (Control= plants incubated without oil; oil= plants incubated with oil, and check = plants not incubated).

NS: Not significantly different as determined by Tuckey multiple-range test at the 5\% confidence level $(\mathrm{P} \leq 0.05)$.

\section{Effect of mixed plantation on $A$. peregrina growth}

The results confirmed that $A$. peregrina plants were tolerant to Eucalyptus spp. effect under the field conditions. A. peregrina diameter and height growth (Fig. $4 \mathrm{~A}$ and B), did not differ significantly between the single and mixed stands of $E$. camaldulensis plus $M$. urundeuva.

In the study conducted by Scotti and Côrrea (2004) in the Legal Reserve of Jaíba-Minas Gerais, the plants of $A$. peregrina which were inoculated with Rhizobia and associated with AM, showed a significant increment in height and total nitrogen content over that non-inoculated plants The growth in height and diameter in the $E$. camaldulensis in treatment 5 was larger where this was in consortium and received the inoculation showing, thus, the inoculation benefit for $E$. camaldulensis (Fig. 5).

The success of field results clearly confirmed the tolerance of A. peregrina to allelophatic effect of essential oil of E. camaldulensis.
A

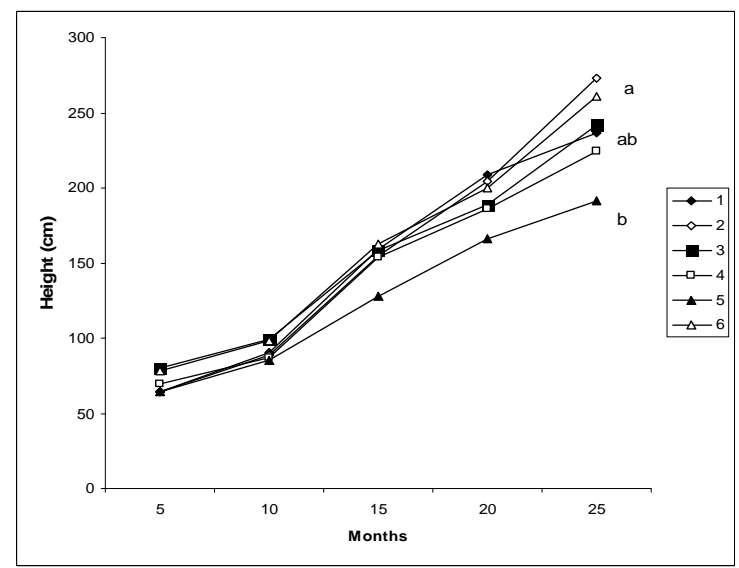

B

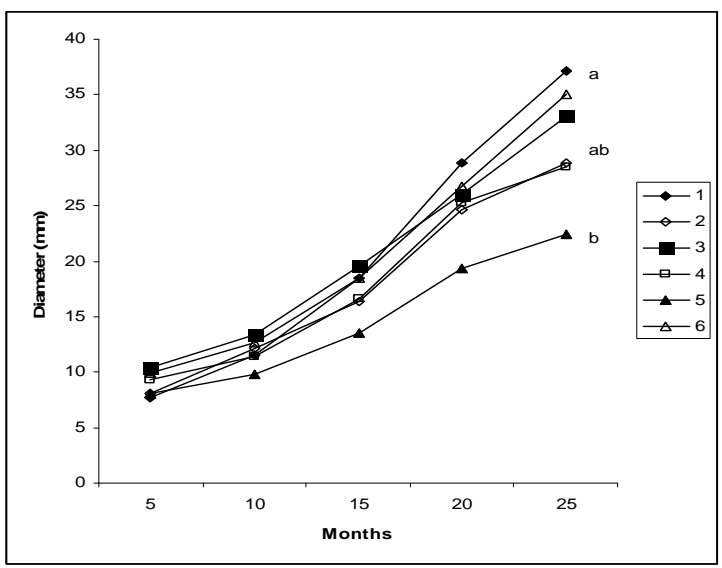

Figure 4 - Effect of intercropped plantation on height (A) and diameter (B) growth of $A$. peregrina under different treatments: 1- Single plantation of A. peregrina, 2- Single plantation of A. peregrina inoculated with Rhizobia and mycorrizal fungi (AMF). 3Mixed plantation of A. peregrina $+E$. camaldulensis $+M$. urundeuva. 4-Mixed plantation of A. peregrina (Rhizobia + AMF $)+E$. camaldulensis $+M$. urundeuva,5Mixed plantation of A. peregrina $+E$. camaldulensis $(\mathrm{AMF})+M$. urundeuva 6Mixed plantation of A. peregrina (Rhizobia $+\mathrm{AMF})+$ E. camaldulensis $(\mathrm{AMF})+M$. urundeuva. Means with different letters are significantly different as determined by Tuckey multiple-range test at the $5 \%$ confidence level $(\mathrm{P} \leq 0.05)$. 
A

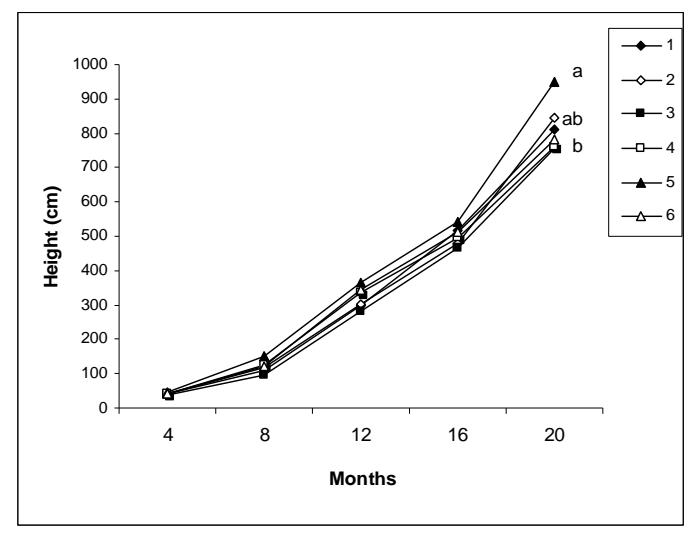

B

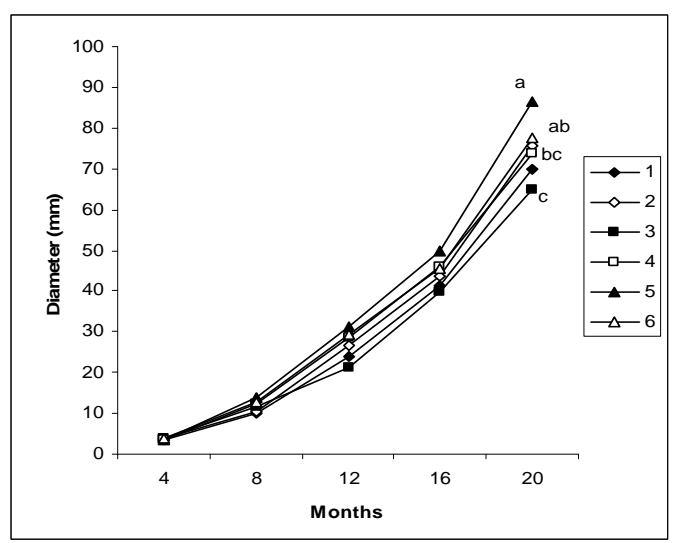

Figure 5 - Effect of intercropped plantation on height (A) and diameter (B) growth of $E$. camaldulensis under different treatments: 1- Single plantation of E. camaldulensis , 2Single plantation of E. camaldulensis + AMF 3- Mixed plantation of A. peregrina $+E$. camaldulensis $+M$. urundeuva. 4-Mixed plantation of A. peregrina (Rhizobia + AMF) + E. camaldulensis $+M$. urundeuva,5- Mixed plantation of $A$. peregrina $+E$. camaldulensis $(\mathrm{AMF})+$ M. urundeuva 6- Mixed plantation of A. peregrina (Rhizobia $+\mathrm{AMF})+$ E. camaldulensis $(\mathrm{AMF})+$ M. urundeuva .

Means with different letters are significantly different as determined by Tuckey multiple-range test at the $5 \%$ confidence level $(\mathrm{P} \leq 0.05)$.

There are reports that some species are more tolerant than others to the inhibitory effects of Eucalyptus spp. oil over germination and plant growth (Kohli and Singh 1991), depending on the physiological and biochemical proprieties of the plants (Hasegawa et al. 1992, Suzuki et al. 2001; Iqbal et al. 2002). The similar occurred in the present study, which showed the high tolerance of $A$. peregrina plants to $E$. grandis and $E$. camaldulensis oils. Several uthors have attributed the natural allelophatic effect in the native forest, as an important control mechanism (Mallik 1992), modeling the plant community structure and their composition (Fischer 1986; Mizutani 1989; Seigler 1996). Under the conditions, the Eucalyptus species showed prejudicial effects for the adjacent cultures (Jensen 1983; Onyewotu 1985; Igbuanugo 1988a, b; Kohli 1990; Mallik and Sharma 1990; Puri and Bangawa 1992; Singh and Kohli 1992).

However, Duarte et al, (2006) found that $E$. contortisiliquum plants could be intercropped with E. grandis for reforestation in agroforestry systems under the same field conditions of the current study. Similarly, the E. contortisiliquum growth was not inhibited when intercropped with $E$. grandis.

Scotti and Côrrea (2004) confirmed the positive effect of the double inoculation on the growth of
A. peregrina. Also, they found that in plots where A. peregrina was inoculated, the growth and survival of intercropped plants as Myracrodruon urundeuva were favored. Chaves et al. (2006), confirmed the benefit of inoculation for $A$. peregrina growth.

The literature shows that soil microorganisms population may be also inhibited by allelophatic effect of Eucalyptus. Inhibition of soil bacteria (DELLA BRUNA et al. 1989) or nitrogen fixing bacteria with reduction of Leucaena leucocephala nodulation (Moura al. 1996) were registered. However, tolerant rhizobia strains were selected.

DUARTE et al, 2006 also showed that inoculated rhizobia strain for E. contortisiliquum was also tolerant to allelopathic effect of $E$. grandis. Similarly, the inoculated strain BHICB-A-10 appeared to be tolerant to E. calmadulensis effect since the growth of all inoculated plants (treatments 2 and 6) were higher than noninoculated plants (treatments 1 and 5) as showed in Figure 4.

However, the literature shows that soil microorganisms may be inhibited by the allelophatic effect of Eucalyptus. As well as the arbuscular mycorrhizal fungi (AMF) can promote the plant tolerance to heavy metals and have been indicated for use in revegetation processes of the 
soils impacted by copper mining (Lins et al. 2007). Besides to the tolerance to E. camaldulensis oil, the strain BHICB -A10 revealed to be an efficient nitrogen fixing strain as demonstrated by Pagano et al. 2008 in the same experiment in semiarid. These authors demonstrated the advantage of the double inoculation of rhizobia and AMF to $A$. peregrina growth through the improvement of dry matter, plant nutrient and especially total $\mathrm{N}$ content.

In this in vitro assays, the oil extracted from $E$. camaldulensis and E. grandis leaves did not show inhibitory effect on the growth $A$. peregrine. Under the field conditions, A. peregrina could be cultivated in mixture with E. camaldulensis, especially when inoculations of both the species were done.

\section{REFERENCES}

Araújo FS. Estudos fitogeográficos do carrasco no nordeste do Brasil [thesis]. Campinas: Instituto de Biologia, Universidade Estadual de Campinas. 1998.

Bhaskar V, Dasappa V. Ground flora in Eucalyptus plantation of different ages. In: Sharma JK, Nair CS, Kedarnath S, Konda S. Eucalyptus in India - Past, Present, and Future... India: Kerala, Forest Research Institute, 1986, p. 213-224.

Brazilian Pharmacopoeia. 4.ed. São Paulo: Atheneu. 1988.

Carvalho PER. Brazilian tree species: silvicultural recommendations, wood potential and use. Brasilia: Eds. Colombo EMBRAPA-CNPF/SPI;1994.

Chaves L deLB, Carneiro JG de A, Barroso DG. Crescimento de mudas de Anadenanthera macrocarpa (Benth) Brenan (angico -vermelho) em substrato fertilizado e inoculado com rizóbio. Rev. Árvore. 2006; 30(6): 911-9.

Dayzy RL, Kohli RK. Fresh matter is not an appropriate relation unit for chlorophill contetnt: esperience from experiments on effects of herbicides and allelopathic substances. Photosynthetica. 1991; 25: $144-6$.

Della-Bruna E, Fernandes B, Almeida Filho JH, Barros NF. Efeito do extrato de serrapilheira de Eucalyptus sobre o crescimento microbiano. Pesq. Agropec. Bras. 1989; 24:1523-28.

Del moral R, Willis RJ, Ashton DH. Suppression of coastal heath vegetation by Eucalyptus baxteri. Aust. J. Bot. 1978. 26: 203-20.
De-Bell D, Whitesell CD, Schubert TH. Mixed plantation of Eucalyptus and leguminous tree enhance biomass production. Res. Paper PSW-175. Berkeley, C.A: Pacific Southwest forest and Range Experiment Station Forest Service. U.S. Department of Agriculture. 1985.

Deuber R. Ciência das plantas daninhas: fundamentos. São Paulo: Ed. FUNEP;1992.

Duarte NF, Uber-Bucek E, Karam D, Sá N, Scotti MRM. Mixed field plantation of native and exotic species in semi-arid Brazil. Aust J Bot. 2006; 54:755764.

Fischer NH. The function of mono and sesquiterpenes as plant germination and growth regulators. In: Putnam, A.R., Tang, C.S. (Eds.), The Science of Allelopathy. New York: Wiley; 1986. p. 203-218.

Gonçalves LMB, Moura VTL, Marques MS, Scotti MRML. Effects of acidity and lime on growth and nodulation of Leucaena leucocephala (Lam) de Wit in Eucalytus soil. Indian J. Agric. Res. 2000; 34: 22934.

Hasegawa K, Mizutani J, Kosemura S, Yamamura S. Isolation and identification of lepidimoide, a new allelopathic substance from mucilage of germinated cress seeds. Plant Physiol. 1992; 100: 1059-61.

Igboanugo ABI. Preliminary studies on phytotoxic growth and yield inhibitions of Capsicum annuum by Eucalyptus citriodora. Biol. Agricul. Horticult. 1988a; 5:339- 45.

Igboanugo, ABI. Morphology and yield of chili (Capsicum annuum) in relation to distance from lemonscented eucalyptus (Eucalyptus citriodora) stands. Indian J. Agric. Sci., 1988b; 58: 317-9.

Iqbal Z, Hiradate S, Noda A, Isojima S, Fujii Y. Allelopathy of buckwheat: Assessment of allelopathic potential of extract of aerial parts of buckwheat and identification of fagomine and other related alkaloids as allelochemicals. Weed Biol. Manag. 2002; 2:11015.

Jensen AM. Shelterbelt Effects. In: Tropical and Temperate Zones. International Development Research Centre, Canada: Manuscript Reports, IDRC-MR80-e, 1983.

Khanna PK. Nutrient cycling under mixed-species tree systems in southeast Asia. Agroforestry Sys. 1997; 38: 99-120.

Kohli RK. Allelopathic Potential of Eucalyptus. Project Report MAB-DOEn. Project, India, 1990.

Kohli RK, Singh D. Allelopathic impact of volatile components from Eucalyptus on crop plants. Biol. Plantarum. 1991; 33: 475-83. 
Kohli RK, Singh D, Rani, D. Allelopathic potential of volatile terpenes of Eucalyptus. In: Environmental Concerns in Rights-of-Way Management. Doucet, G. J., Seguin, C., and Giuere, M., Eds., Vicepresidence.Environment Hydro-Quebec, Montreal, Canada: 1992; p. 102-106.

Kohli RK, Batish DR. Singh HP. Eucalypt oils for the control of Parthenium (Partenium hysterophorus L.). Crop prot. 1998; 17:119-24.

Lins CEL, Maia LC, Cavalcante UMT, Sampaio Barreto EVS. Efeito de fungos micorrízicos arbusculares no crescimento de mudas de Leucaena leucocephala (Lam.) de Wit. em solos de caatinga sob impacto de mineração de cobre. Rev. Árvore. 2007; 31: 355-63.

Linchenthaler HR, Wellburn AR. Determination of total carotenoides and clorophyll $\mathrm{a}$ and $\mathrm{b}$ of leaf extracts in diferent solventes. Biochem. Soc. Trans.1983; 11: 1591-92.

Lorenzi H. Árvores brasileiras: manual de identificação e cultivo de plantas arbóreas nativas do Brasil. Nova Odessa: Plantarum, 1992. 352p.

Malik RS, Sharma K. Moisture extraction and crop yield as function of distance from a row of Eucalyptus tereticornis. Agroforestry Syst. 1990; 12: 187-195.

Mallik AU. Possible role of allelopathy in growth inhibition of softwood seedling in Newfoundland. In: S.J.H Rizvi and V. Rixvi (eds). Allelopathy. Basic and Applied aspects. Chapman e Hall, London, 1992, p. 321-340.

Marques MS, Pagano MC, Scotti MRMML. Dual inoculation of woody legume (Centrolobium tomentosum) with rhizobia and mycorrhizal fungi in southeastern Brazil. Agroforestry Syst.. Holanda, . 2001; 52:107-17.

May BM, Attiwill PM. Nitrogen-fixation by Acacia dealbata and changes in soil properties 5 years after mechanical disturbance or slash-burning following timber harvest. Forest Ecol. Manag. 2003:18, 339-55.

May FE, Ash JE. An assessement of the allelopathic potencial of Eucalyptus. Australian J. Bot. 1990; 38: 245-54.

Mizutani J. Plant allelochemicals and their roles. In: Chou CH, Waller GR. (Eds.), Phytochemical Ecology: Allelochemicals, Mycotoxins and Insect Pheromones and Allomones. Taipei: Institute of Botany, Academia Sinica. , 1989. p. 155-165.
Moura VTL, Marques MS, Gonçalves LMB, Scotti MRMML, Valle MTS, Lemos Filho JP. Nodulação e crescimento de leguminosas cultivadas em solos coletados sob eucaliptal e sob mata atlântica: relação com os efeitos alelopáticos do Eucalyptus. R.Bras. Ci. Solos. 1996; 20: 399-405.

Muller CH, Muller, WH, Haines BL. Volatile growth inhibitors produced by shrub. Science. 1964; 143: 471-3.

Onyewotu LOZ. Shelterbelt effects on the yield of agricultural crops: a case study of a semi-arid environment in Northern Nigeria. IDRC Report, Canada, 1985.

Pagano MC, Cabello MC, Bellote AF, Sá Carneiro NM, Scotti MR. Intercropping system of tropical leguminous species and Eucalyptus camaldulensis, inoculated with rhizobia and/or mycorrhizal fungi in semiarid Brazil. Agroforest Syst. 2008; 74: 231-242

Puri S, Bangawa KS. Effect of trees on the yield of irrigated wheat crop in semi-arid regions. Agroforestry Syst. 1992; 20: 229-241.

Rizzini CT. Tratado de Fitogeografia do Brasil. São Paulo: Ed. Humanismo, Ciência e Tecnologia. 1979.

Scotti MR, Corrêa EJA. Growth and litter decomposition of woody species inoculated with rizobia and arbuscular mycorrhizal fungi in Semiarid Brazil. Ann. For. Sci. 2004, 61:87-95.

Seigler DS. Chemistry and mechanisms of allelopathic interactions. Agron. J. 1996; 88: 876-85.

Singh A, Dhanda RS, Ralhan PK. Performance of wheat varieties under poplar (Populus deltoids Bartr.) plantations in Punjab (India), Agroforestry Syst. 1993;22: 83-6.

Singh D, Kohli RK. Impact of Eucalyptus tereticornis Sm. shelterbelts on crops. Agroforestry Syst.1992; 20: 253-66,

Somasegaran P, Hoben HJ. Methods in LegumeRhizobium Technology. Niftal. Hawaii:University of Hawaii;1985.

Suzuki T, Usui I, Tomita-Yokotani KY, Kono S, Tsubura H, Miki Y. Effect of acid extracts of tomato (Daucus carota L.) wastes from the food industry on the growth of some crops and weeds. Weed Biol. Manag. 2001: 226-30.

Suresh KK, Rai RSV. Studies on the allelopathic effects of some agroforestry tree crops. Int. Tree Crops J. $1987 ; 4 ; 109-15$. 